INTERNATIONAL JOURNAL OF MULTIDisciplinARY RESEARCH AND ANALYSis

ISSN(print): 2643-9840, ISSN(online): 2643-9875

Volume 05 Issue 02 February 2022

DOI: 10.47191/ijmra/v5-i2-45, Impact Factor: 6.072

Page No. 564-567

\title{
Description of Some Anthropometric Indicators of 7-10 Year-Old Student Girls
}

\section{F. Mirzabekova ${ }^{1}$, M.Xolmirzaeva ${ }^{2}$, M.Askarova ${ }^{3}$}

ANNOTATION: The growth and development of the organ system at different ages of the human body is of particular importance. Differences in morphological and physiological indicators of the organism are noticeable, especially in the early school years, when the growth rate is significantly higher. The study of some morphologically important physical development indicators of young school-age children, the study of health indicators is of great importance. This article provides a statistical analysis of some anthropometric indicators of primary school girls of secondary school. Based on the results, appropriate suggestions and conclusions are made.

KEYWORDS: adaptation, growth patterns, physical development, anthropometric indicators, growth dynamics, individual development, statistical analysis, degree of inevitability.

\section{INTRODUCTION}

In today's world, the issue of creating conditions for the healthy physical, mental and emotional development of children is a priority for the future of any society. Therefore, in order to constantly monitor the level of physical development and health of school-age children in the educational process, conduct physiometric, anthropometric research, develop and implement a set of measures to improve their health, which in turn will prevent various diseases. scientific and practical significance.

The optimal development of the level of physical activity of students in scientific research conducted in many countries around the world requires taking into account the individual characteristics of school students in relation to their physiological age in the organization of physical education classes. Studies have shown that under the influence of reduced levels of physical activity in children and adolescents in the body of the musculoskeletal system, the activity of the main functional systems of the body decreases and, in turn, increases the susceptibility to various diseases. Determining the age, gender-specific characteristics of primary school students at the level of physical development, assessment of physiological changes in them on the basis of morphofunctional system indicators are considered as promising areas of research currently underway. Therefore, in determining the health of primary school students, the analysis on the basis of indicators of physical development and readiness, the development of a set of medical and pedagogical correction, preventive measures are of great scientific and practical importance.

The response of morpho-physiological systems of the human body to the effects of various endogenous and exogenous factors is determined directly by the somatotypological characteristics of the organism, depending on the physiological age. In particular, indicators of physical development of children's bodies are considered as a reliable indicator of the successful implementation of adaptive capabilities under the influence of various factors [Chub I.S., 2013; 3-b.].

Assessment of the level of physical development on the basis of morphometric indicators allows to analyze the state of adaptation of the organism to the external environment [Shilova O.Yu., 2011; Pp. 29-36; Kirilova I.A., 2017; 5-b.].

In turn, the physical development of children is a key indicator for assessing the health status of them and the population under analysis in general [Rakhimov M. I., 2011; Pp. 57-59; Tulyakova O.V., Avdeeva M.S., Sizova E.N., 2012; Pp. 74-87; Kirilova, 2017; 5-b.].

Physical development is an integral indicator of the health of the growing human body, and it is the period of schooling is recorded as the optimal period for the formation of healthy physical development of children and adolescents [Safronov AA, Arislanov IT, 2013; 455-b.].

Monitoring of physical development is also important in terms of determining the level of development of the body of children of different ages, as well as the timely recording of deviations from the norm and the implementation of appropriate corrections. [Antonova A.A., 2012; Pp. 26-29; Kirilova I.A., 2017; 5-b.]. 


\section{Description of Some Anthropometric Indicators of 7-10 Year-Old Student Girls}

\section{RESEARCH MATERIALS AND METHODS}

In research, the standard method of measuring the height $(\mathrm{cm})$ of students using a stationary height measuring device (GOST 16371-93, 19917-93) [Erenkov V.A., 1984; 10-336-b .; Safronov A.A., Arislanov I.T, 2013; Pp. 455-458; Pilkevich N.B, 2013; P.], in the upright position of the test subject, the base of the legs on the special platform is paired and the torso is upright, the shoulders are in the correct position, the hump and the middle of the shovels are placed on the device. Attention was paid to the fact that the heel of the body, buttocks, chest and neck area of the head touch the measuring column, the eye area and the lower part of the ear supra are located in one plane. The head is held in an upright position, facing forward, the sliding special plate (bar) of the measuring device is lowered to the position of touching the top of the head, and the value (cm) is recorded [Muratova I.V., 2009; Pp. 59-61].

Measurement of body weight $(\mathrm{kg})$. In research, the standard method of measuring the body weight of primary school students using a medical scale (TU 9441-004-00226425-2005) [Rakhimov M. I., 2011; 10-336-b .; Korobko R.P. 2002; Pp. 455-458; Karakeeva G.J., 2012; 30-b .; Nechaev M.P., 2001; Pp. 3-24] , in other words, the body weight of the test student was determined by weighing on a medical scale when he took off his clothes, except for underwear (the accuracy of the measurement was $\pm 50-$ $100 \mathrm{~g}$ ). Measuring the length of the chest circumference (cm) - standard method [Rakhimov M. I., 2011; 10-336-b .; Korobko R.P., 2002; Pp. 455-458; Karakeeva G.J., 2012; P. 30], in which the value of this indicator in the test student was measured using a centimeter measuring tape (GOST R 50444-92) at rest, maximum exhalation, maximum exhalation. In this case, the students' chest circumference $(\mathrm{cm})$ was measured at the level of the sternum line (with a measurement accuracy of $\pm 0.5 \mathrm{~cm}$ ) with the arms down along the torso (Pustozerov A.I., Gostev A.G., 2008; 7-14-p .;].

\section{OBTAINED RESULTS AND THEIR ANALYSES}

The results obtained are as follows: L.V. Denisova et al. (2008) using mathematical and statistical processing [Albitsky V.Y .; 125459-b .; Bakanov I.M, 2008; 5-312-b .; Anisimova E.A., 2014; 7-127-b .; Korobko R.P., 2002; 455-458-p.].

The results are presented in the form $\mathrm{M} \pm \mathrm{t}$ of the results of experiments performed at $\mathrm{p}$ times repetition, where $\mathrm{M}$ is the arithmetic mean and $t$ is the standard error value.

Also, the results of the experiment showed that the level of statistical reliability of values between groups was calculated on the basis of the Student t-criterion and was assessed as statistically reliable at values of $<<0.05, r<0.01$. The degree of reliability of the difference between the values of the two age groups was calculated according to the Student's criterion, using the following

$$
\text { Formula: } t=\frac{\bar{x}_{1}-\bar{x}_{2}}{\sqrt{m_{1}^{2}+m_{2}^{2}}}
$$

At the initial stage of the observations, the analysis of physical development indicators based on the main anthropometric indicators of primary school students (7-10 years) - body weight $(\mathrm{kg})$, height $(\mathrm{cm})$ and chest circumference $(\mathrm{cm})$ was carried out. In our observations, we studied the anthropometric indicators of primary school girls (7-10 years) of secondary school No. 30 in Andijan. A total of 78 healthy and volunteer girls were involved in the follow-up.

\section{Analysis of the obtained results.}

In our study, the indicators of physical development were body weight, height, chest circumference (at rest, in front of the mammary glands during deep breathing and deep breathing), and statistical analysis, and the results were as follows.

\section{1-table}

Values of some anthropometric indicators $(\mathrm{M} \pm \mathrm{m}$ ) of primary school students (7-10 years old) of secondary school No. 30 in Andijan, Andijan region

\begin{tabular}{|l|l|l|l|l|}
\hline \multirow{2}{*}{ Anthropo-metric indicators } & \multicolumn{2}{|l|}{ Girls $(n=78)$} \\
\cline { 2 - 5 } & $\begin{array}{l}7 \text { years old } \\
(n=16)\end{array}$ & 8 years old $(n=11)$ & $\begin{array}{l}9 \text { years old } \\
(n=17)\end{array}$ & 10 years old $(n=22)$ \\
\hline Weight $(\mathrm{kg})$ & $23,2 \pm 0,3$ & $24,2 \pm 0,3$ & $25,9 \pm 0,4^{*}$ & $33,1 \pm 0,5^{* *}$ \\
\hline Height (cm) & $122,7 \pm 6,2$ & $127,3 \pm 5,9^{*}$ & $136,7 \pm 5,3^{* *}$ & $143,6 \pm 6,8^{* *}$ \\
\hline $\begin{array}{l}\text { Chest circumference (cm): at } \\
\text { rest; in the state of maximum } \\
\text { respiration; in the case of } \\
\text { maximum exhalation }\end{array}$ & $58,7 \pm 0,5$ & $65,4 \pm 0,5$ & $70,6 \pm 0,7^{*}$ & $78,7 \pm 0,4$ \\
\cline { 2 - 5 } & $60,7 \pm 0,5$ & $68,8 \pm 0,4$ & $76,4 \pm 0,5^{*}$ & $82,2 \pm 0,6^{* *}$ \\
\hline
\end{tabular}

Note: Represents the level of statistical reliability of the difference between the values of $7-10$ years $\left(*-r<0.05 ; *^{*}-r<0.01\right)$. 


\section{Description of Some Anthropometric Indicators of 7-10 Year-Old Student Girls}

The average body weight of primary school students was $23.2 \pm 0.3 \mathrm{~kg}$ at the age of $7,24.2 \pm 0.3 \mathrm{~kg}$ at the age of $8,25.9 \pm 0.4 \mathrm{~kg}$ at the age of 9 , and 33.1 at the age of $10 . \pm 0.5 \mathrm{~kg}$.

The increase in body weight among schoolchildren aged 7-10 years was a total of $9.9 \mathrm{~kg}$. It was found that at the age of 7-8 years $1.0 \mathrm{~kg}$ and at the age of 8-9 years $1.7 \mathrm{~kg}$, and at the age of 9-10 years the body weight increased by $7.2 \mathrm{~kg}$.

The average height of schoolchildren was $122.7 \pm 6.2 \mathrm{~cm}$ at the age of $7,127.3 \pm 5.9 \mathrm{~cm}$ at the age of $8,136.6 \pm 5.3 \mathrm{~cm}$ at the age of 9 , and $143.8 \pm 6.8$ at the age of 10 . smni.

It was found that the average growth rate of height in schoolchildren at the age of 7-10 years was $21.1 \mathrm{~cm}$, at the age of 7-8 years $-4.6 \mathrm{~cm}$, at the age of 8-9 years $-9.3 \mathrm{~cm}$, at the age of 9-10 years $-7.2 \mathrm{~kg}$.

In the next part of our observations, the length of the chest circumference (in front of the mammary glands at rest) was determined. At the same time, the average length of the chest circumference in schoolchildren at the age of 7-10 years at rest was $58.7 \pm 0.5 \mathrm{~cm}$ at the age of 7 years, $65.4 \pm 0.5 \mathrm{~cm}$ at the age of 8 years, $70.6 \pm 0.7 \mathrm{~cm}$ at the age of 9 years. age was found to be $78.7 \pm 0.4 \mathrm{~cm}$.

It was found that the rate of increase in the length of the chest circumference in schoolchildren increased by $20.0 \mathrm{~cm}$ at the age of 7-10 years, by $6.7 \mathrm{~cm}$ at the age of 7-8 years, by $5.2 \mathrm{~cm}$ at the age of 8-9 years, and by $8.1 \mathrm{~cm}$ at the age of 9-10 years.

In observations, the average length of the chest circumference in schoolchildren was $60.7 \pm 0.5 \mathrm{~cm}$ at the age of 7 years, $68.8 \pm$ $0.4 \mathrm{~cm}$ at the age of 8 years, $76.4 \pm 0.5 \mathrm{~cm}$ at the age of 9 years. age was found to be $82.2 \pm 0.6 \mathrm{~cm}$.

The rate of increase in the value of the circumference of the chest at the age of 7-10 years is $21.6 \mathrm{~cm}$ at the age of 7-10 years, 8.1 $\mathrm{cm}$ at the age of 7-8 years, 7.6 years at the age of 8-9 years. $\mathrm{cm}$, and at the age of 9-10 years it increased by $5.8 \mathrm{~cm}$.

In the case of maximal exhalation of students aged 7-10 years, the average value was $57.0 \pm 0.6 \mathrm{~cm}$ at the age of 7 years $64.3 \pm$ $0.4 \mathrm{~cm}$ at the age of 8 years $69.5 \pm 0.5 \mathrm{~cm}$ at the age of 9 years $74,4 \pm 0.6 \mathrm{~cm}$.

It was found that the increase in the value of the circumference of the chest among schoolchildren was $17.4 \mathrm{~cm}$ at the age of 710 years, $7.3 \mathrm{~cm}$ at the age of 7-8 years, $5.2 \mathrm{~cm}$ at the age of 8-9 years, and $4.6 \mathrm{~cm}$ at the age of 9-10 years.

Based on the results of the study, it can be seen that the values of anthropometric indicators (body weight, height, chest circumference) studied in primary school girls №30-located in Andijan increased linearly between the ages of 7-10 years.

\section{CONCLUSION}

The study of physical development of children aged 7-10 years is of great importance in determining the level of health of the younger generation. Based on the results of our research, we can draw the following conclusions.

1. Body weight is increasing dynamically with age. The difference between 8-9 years is statistically inevitable ( $r$ $<0.05)$.

2. The overall length of the neck is also based on the laws of growth and development, and is increasing with age. The differences between 9-10 years were significant and statistically unavoidable $(r<0.01)$.

3. Age-related increases in chest circumference were observed in all three cases (at rest, deep breathing, and deep breathing) with age-related differences. and can be clearly seen in cases of deep breathing.

4. As a result of the above analysis, it can be seen that the growth dynamics between the ages of 9 and 10 is clearly visible in all indicators. This means that growth and development are accelerated between the ages of 9-10 and 7-8 years.

\section{SUGGESTION}

As we continue to analyze our findings and follow up, we would suggest that we continue to conduct regular surveys to find out the level of preventive health of young school-age children.

\section{REFERENCES}

1) Albitskiy V.Y., Antonova E.V., Baranov A.A., Bondar V.I., Volkov I.M., Methodological recommendations for the study of the incidence of children's population // Moskva, 2009. - $40 \mathrm{p}$.

2) Anisimova E.A., Lukina G.A., Anisimov D.I. Age Variability of Total Body Sizes and Body Types of Women // Meditsina $i$ zdravooxranenie. / Moscow, 2014. - T.4. - №6. - S.918-920.

3) Antonova A.A., Chentsova S.N., Serdyukov V.G. Comparative characteristics of the physical development of children // Astrakhan. med. magazine. - Astraxan, 2012. - №4. - S.26-29.

4) Bakanov I.M. Hygienic substantiation of the motor mode of primary school students of full-time schools // Dissertatsiya k.med.n. / Moscow, 2007. - 199 p.

5) Erenkov V.A. Clinical study of a child // - Kiev. "Zdorove", 1984. - S.10-336. 


\section{Description of Some Anthropometric Indicators of 7-10 Year-Old Student Girls}

6) Gorelov A.A., Gorelova T.A. Education in informational society // Alma mater (Vestnik vysshey shkolb). / Moscow, 2008. - №10. - S.43-46.

7) Ilyasov A.S., Shukurbekova F.F. Comparative analysis of the growth of adolescents and young, living in different ecological zones of the Navoi region of the Republic of Uzbekistan // Morphology / Kyrgyzstan, 2012. - T.141. - №3. - S.65.

8) Karakeeva G.J Health status of children from large families // Diss.... k.med.n. / Bishkek, 2012. P.5-75.

9) Korobko R.P Physical development and functional state of the cardiovascular and respiratory systems in children 7-12 years old, indigenous residents of Osh // Abstract diss. ... K.b.n. (03.00.13 - physiology). / /Bishkek, 2002. - S.3-18.

10) Kirilova I.A. Assessment of physical development as a population characteristic of the child population of the Irkutsk region. //Abstract diss. ... k.b.n. (03.02.08 - ecology). - Irkutsk, 2017. - P.5-20.

11) Muratova I.V. Assessment of physical development and physical fitness of primary school students of secondary schools of the Republic of Mordovia // Vestnik sportivnoy nauki. - Russia, 2009. - №1.- P.59-61.

12) Nechaev M.P. Theoretical foundations for the development of the educational potential of the educational environment of the school // Dissertatsiya d.med.n. / Moscow, 2001. - 503 p.

13) Pilkevich N.B. Anthropometric indicators of physical development in children with visual impairments aged 7-10 years // Liki Ukraïni plyus. - Ukraine, 2013. - №2 (15). - S.28-30.

14) Pustozerov A.I., Gostev A.G. Health-improving physical culture // Ucheb. - metod. posobie. - Chelyabinsk. - Izd - vo YuUrGU, 2008. - 85 p.

15) Raximov M. I. Indicators of the physical development of children and adolescents aged 5-16 // Filologiya i kultura./ Irkutsk, 2011. - №24. - S.57-59.

16) Safronov A.A., Arislanov I.T. Dynamics of physical development and physical training uchashchixsya 5-6 classes // Young uchenyy. -Moscow, 2013. - №7. - S.455-458.

17) Tulyakova O.V., Avdeeva M.S., Sizova E.N. Regional features of the physical development of boys and girls in Kirov at birth, at 1 year and at 7 years // Novye issled. - Moscow, 2012. - №13.

$$
\text { - } \quad \text { S.74-87. }
$$

18) Chub I.S. Dynamics of indicators of cardiac rhythm in the process of cognitive activity in children of different somatotypes. Abstract diss. ... k.b.n. (03.03.01 - physiology). - Arkhangelsk, 2013. - S.3-20.

19) Shilova O.Yu. Modern trends in physical development in the youthful period of ontogenesis (Review) // Human Ecology. - Moscow, 2011. - №4. - S.29-36. 